\title{
Leukemia inhibitory factor ligand-receptor signaling is important for uterine receptivity and implantation in golden hamsters (Mesocricetus auratus)
}

\author{
Tianbing Ding, Haengseok Song ${ }^{1}$, Xiaohong Wang, Atanu Khatua ${ }^{2}$ and Bibhash C Paria \\ Division of Neonatology, Department of Pediatrics, Vanderbilt University Medical Center, 1125 MRB IV/Light Hall, \\ 2215 B. Garland Avenue, Nashville, Tennessee 37232-0656, USA, ${ }^{1}$ Laboratory of Reproductive Biology and Infertility, \\ Cheil General Hospital and Women's Healthcare Center, Seoul 100-380, South Korea and ${ }^{2}$ Meharry Medical College, \\ Comprehensive Center for Health Disparities Research in HIV, Nashville, Tennessee 37208, USA
}

Correspondence should be addressed to B C Paria; Email: bc.paria@vanderbilt.edu

\begin{abstract}
Blastocyst implantation occurs in the progesterone-primed uterus of hamsters, but not in mice where the progesterone-primed uterus requires estrogen influence. Leukemia inhibitory factor ( $($ if), an estrogen-regulated gene in mice, is an absolutely needed cytokine for uterine receptivity and implantation in this species. This study aimed to evaluate the importance of Lif ligand-receptor signaling during uterine receptivity and implantation in hamsters. We investigated whether or not the uterine expression patterns of Lif and its receptors, Lif-r and gp130, during the periimplantation period of pregnancy and its hormonal regulation in the ovariectomized hamster correlate with some of the vital phases of uterine changes during early pregnancy. Uterine Lif, Lif-r, and gp130 mRNA expressions were examined by Northern and in situ hybridization. During the uterine preparatory phase for implantation, Lif, Lif-r, and gp130 were expressed either in the gland, luminal epithelium or both. As the implantation process began, Lif expression was minimal, but Lif-r and gp130 extended to the decidual areas. This decidual expression of Lif-r and gp130 was not dependent on the presence of the embryo since these genes were expressed in the sutureinduced deciduomata. We also observed that, while the uterine Lif was induced by estrogen, Lif-r and gp130 were induced by progesterone in ovariectomized hamsters. Additionally, we show that a Lif antibody when instilled intraluminally on day 3 of pregnancy reduced the number of implantation sites. Taken together, these data suggest that Lif signaling is important for uterine receptivity and implantation in hamsters. Reproduction (2008) 135 41-53
\end{abstract}

\section{Introduction}

The hormonal requirements for uterine receptivity and implantation differ among species. The preparation of a receptive uterus for supporting embryo implantation in mice and rats is achieved by sequential effects of ovarian progesterone $\left(\mathrm{P}_{4}\right)$ and estrogen ( $\mathrm{E}$; Yoshinaga \& Adams 1966, Psychoyos 1973, Paria et al. 1993). However, uterine receptivity is regulated only by ovarian $\mathrm{P}_{4}$ in hamsters (Prasad et al. 1960, Orsini \& Meyer 1962, Harper et al. 1969, Wang et al. 2002, 2004, Zhang \& Paria 2006). Studies in the mouse, rat, and agricultural species suggest that cytokines and growth factors produced by the uterine cells in response to ovarian steroids help in preimplantation embryo development and implantation (Carson et al. 2000, Modric et al. 2000, Paria et al. 2002). Among the cytokines studied, leukemia inhibitory factor (Lif) has been established as an essential molecule for uterine receptivity and implantation in mice (Stewart et al. 1992, Song et al. 2000).

Lif is a secreted glycoprotein that exhibits pleiotropic activities in varieties of cellular systems both in vivo and in vitro (Rathjen et al. 1990, Hilton 1992, Gearing 1993). It belongs to a family of ligands that includes interleukin6 (IL-6), IL-11, oncostatin M, ciliary neurotrophic factor, and cardiotropin (Callard \& Gearing 1994). Signal transduction of Lif depends on its binding to a low affinity Lif receptor (Lif-r) subunit, gp190, which causes association of the ligand/receptor complex with another membrane-bound protein, gp130 (Gearing et al. 1992). Lif is mainly expressed in the glandular epithelium of the uterus of mice on day 4 of pregnancy, suggesting its role in the preparation of the receptive uterus for implantation (Stewart et al. 1992, Song et al. 2000). Localized expression of Lif specifically in stromal cells surrounding the implanting mouse blastocyst on day 4 at midnight and the morning of day 5 of pregnancy suggests its involvement in the initiation of the embryo-uterine attachment reaction and subsequent initiation of stromal cell decidualization (Song et al. 2000). The complete failure of blastocyst implantation and uterine stromal cell decidualization in Lif null mice, and the reversal of these processes by exogenous Lif treatment, substantiated the 
importance of this maternal molecule in the process of implantation and decidualization (Stewart et al. 1992). Uterine Lif may also be important for implantation in humans. Significant Lif expression was noted in the endometrium of fertile women rather than that of infertile women (Tsai et al. 2000). The peak expression of Lif and its receptor (Lif-r) was observed in the endometrium at the mid-secretory phase of the menstrual cycle in humans (Cullinan et al. 1996) with maximum expression between days 19 and 25 (Nachtigall et al. 1996). Lif immunostaining in the luminal and glandular epithelial cells was lowest in the follicular phase, moderate in the periovulatory phase, and strongest in the luteal phase (Cullinan et al. 1996). Thus, Lif occupies a central position among many uterine signaling events during uterine receptivity and implantation.

The hormonal requirements for making the uterus receptive and the timing of initiation of implantation are defined in mice (Paria et al. 1993). In contrast, dating of the time of ovulation, chronological development of the secretory endometrium, and the timing of implantation cannot be accurately predicted in humans. It has been demonstrated that in the majority of species, such as the hamster, rabbit, pig, guinea pig, monkey, and human, luteal estrogen is not required to initiate the process of implantation (Deanesly 1960, Prasad et al. 1960, Orsini \& Meyer 1962, Harper et al. 1969, Meyer et al. 1969, Perry et al. 1973, George \& Wilson 1978, Heap et al. 1981, Hoversland et al. 1982, Ghosh et al. 1994, Zegers-Hochschild \& Altieri 1995, Wang et al. 2002, 2004, Zhang \& Paria 2006). A comprehensive study has not been done on the relative involvement and functions of uterine Lif in species where implantation is dependent on ovarian $\mathrm{P}_{4}$, but not $\mathrm{E}$. Thus, the present experiments were undertaken to study the expression of Lif and its receptors during the periimplantation period and their hormonal and embryonic regulation in hamsters. The relative importance of Lif in the hamster uterus during early pregnancy may point to a potential correlation between endometrial Lif expression and the extent of its involvement in maternal-embryo interactions in $\mathrm{P}_{4}$ dependent implantation processes. These studies will also help to distinguish the differences, if any, in the involvement of Lif in the process of implantation across species depending on their steroid requirements to initiate the process of implantation.

\section{Results}

\section{Uterine Lif expression during the periimplantation period in hamsters}

Northern blot analysis of Lif $m R N A$ expression in periimplantation uteri from days 1 to 8

As demonstrated in the mouse uterus (Bhatt et al. 1991), the hamster uterus also showed the presence of a single $\sim 4.2 \mathrm{~kb}$ Lif mRNA transcript from days 1 to 8 of pregnancy. Higher levels of Lif mRNA expression were observed on days 1 and 4 (Fig. 1A). When the intensities of hybridized Lif mRNA bands were normalized with the corresponding Rpl7 bands, the trend of Lif mRNA levels followed closely with the trend of band intensities showing significantly higher levels on days 1 and 4 as compared with its levels on other days of pregnancy (Fig. 1B). Next, in situ hybridization was employed to determine the accumulation of mRNA in specific uterine cell types on various days during early pregnancy.

\section{Cell type-specific expression of Lif mRNAs in periim- plantation uteri}

As reported in mice (Bhatt et al. 1991, Stewart et al. 1992, Song et al. 2000), Lif was expressed in the luminal epithelium on day 1 , but not in day 2 of pregnancy in hamsters. Lif expression started to appear in the luminal epithelium on day 3 and showed distinct accumulation in glandular epithelium, but not in stromal and myometrial cells, on the morning and afternoon of day 4 (Fig. 2). However, a low level of accumulation was maintained in the luminal epithelium (Fig. 2, insert). No implantation-specific accumulation of Lif surrounding the implanting blastocyst was observed on the evening (1700 h) of day 4 in hamsters. Thereafter, Lif mRNA expression remained at
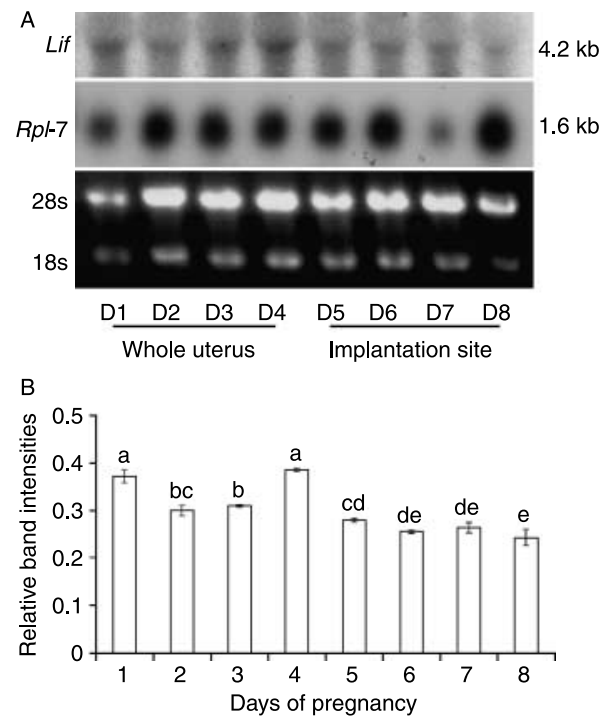

Figure 1 Northern blot analysis of uterine Lif mRNAs in the uterus of hamsters from days 1 to 8 of pregnancy. (A) Representative Northern blot analysis; (B) bar diagram to show relative change in normalized $L$ if band intensities (each Lif band intensity/corresponding Rp/7 band intensity). Total uterine RNA ( $6 \mu \mathrm{g} /$ lane) samples from each day of pregnancy were separated by formaldehyde-agarose gel electrophoresis, transferred, and u.v. cross-linked to nylon membranes and hybridized to ${ }^{32}$ P-labeled Lif probe. The blot was hybridized with $R p / 7$, a housekeeping gene, to confirm integrity, loading, and blotting of RNA samples. Acridine orange-stained gel showing $28 \mathrm{~s}$ and $18 \mathrm{~s}$ rRNAs are also presented. Mean values are plotted. The different letters over bars indicate significant differences $(P<0.05)$. 

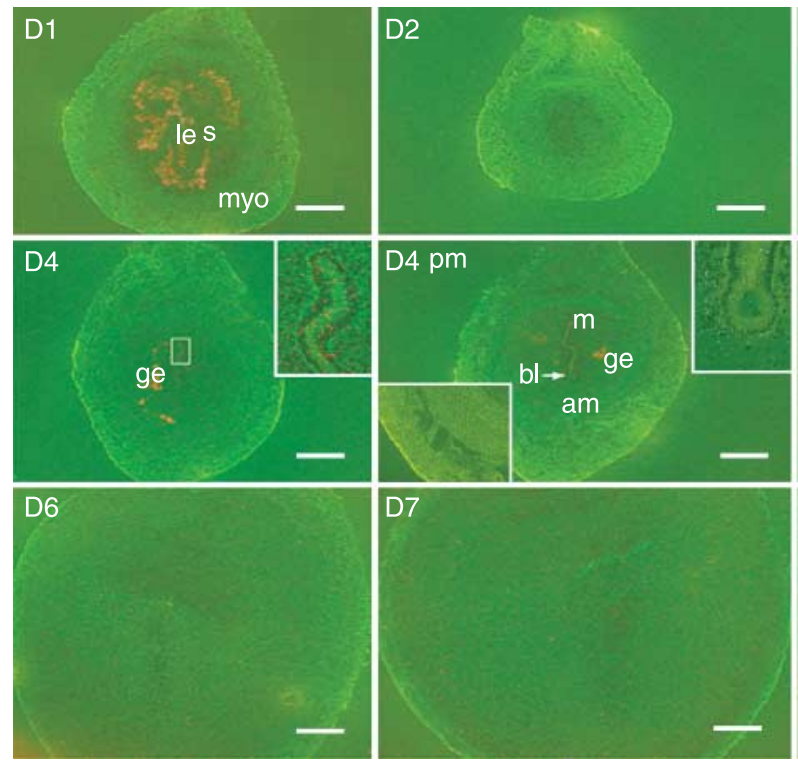
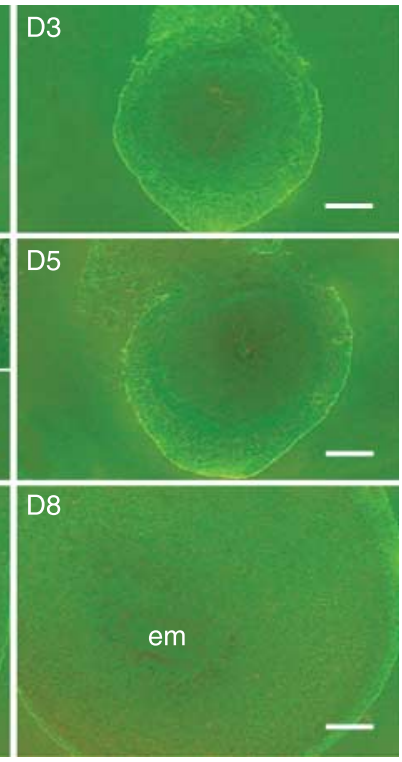

Figure 2 Cross-sections of hamster uteri from days 1 to 8 (D1-D8) of pregnancy were processed for in situ hybridization to demonstrate cell-specific Lif mRNA expression. Insert in D4 shows a higher magnification of Lif mRNA in the luminal epithelium of day 4 uterus. High magnification inserts in $\mathrm{D} 4 \mathrm{pm}$ show no expression of $L$ if $m R N A$ in subluminal stromal (right insert) and myometrial (left insert) cells. Bar $=250 \mu \mathrm{m}$. am, antimesometrial side; bl, blastocyst; D4 pm, Day 41600 h; em, embryo; ge, glandular epithelium; le, luminal epithelium; $m$, mesometrial side; myo, myometrium; s, stroma. low levels in all uterine cell types of the implantation site from days 5 to 8 of pregnancy (Fig. 2).

\section{Cell type-specific Lif expression at the day 5} implantation site of hamsters and mice

Since previous studies demonstrated that $L i f$ is expressed in the stromal cells situated just underneath the luminal epithelium of the day 5 implantation site of mice (Song et al. 2000), we hybridized sections placed on the same glass slide from the day 5 implantation sites of both the mouse and the hamster using a hamster-specific Lif cRNA probe. While Lif expression was at the background level in any uterine cell type of the day 5 implantation site of the hamster, its expression was above the background level in the subluminal stromal cells surrounding the implantation chamber of the mouse (Fig. 3).
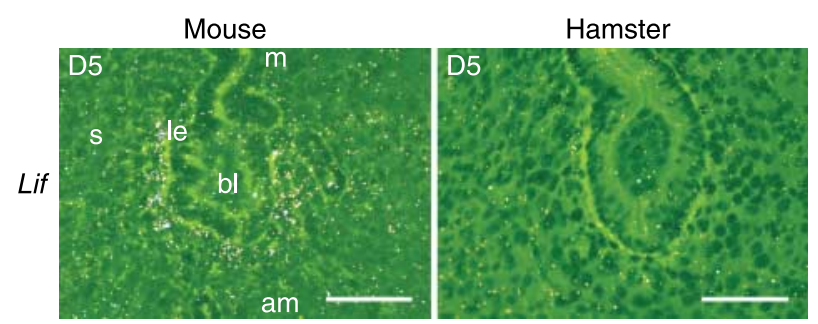

Figure 3 Cross-sections of day 5 implantation sites from mouse and hamster were processed for in situ hybridization to demonstrate species-specific differences in Lif mRNA expression. Implantation sites were collected on the morning of Day $5(0900 \mathrm{~h})$ after an i.v. injection of blue dye as described in Materials and Methods. Bar $=100 \mu \mathrm{m}$. am, antimesometrial side; bl, blastocyst; le, luminal epithelium; $\mathrm{m}$, mesometrial side.
Cell type-specific Lif expression in the day 4 uterus of hypophysectomized $P_{4}$-treated pregnant hamsters

Since uterine preparation for implantation in hamsters occurs in the absence of circulating estrogen, we decided to examine whether uterine Lif expression in the day 4 uterus of $\mathrm{P}_{4}$-treated hypophysectomized hamsters occurs similar to normal pregnancy. Hypophysectomized hamsters treated with $\mathrm{P}_{4}$ showed Lif mRNA expression only in the luminal epithelial cells compared with the control where Lif expression was observed both in the luminal and the glandular epithelia (Fig. 4). The absence of Lif expression in the day 5 implantation site was studied as a negative control. These results suggest that in the absence of ovarian estrogen, either the $\mathrm{P}_{4}$ or the embryo is responsible for the induction of uterine Lif expression.

\section{Hormonal regulation of uterine Lif mRNA expression (Northern blot and in situ analysis)}

As described above, Northern blot analysis showed a $\sim 4.2 \mathrm{~kb}$ transcript of Lif mRNA in total uterine RNA samples (Fig. 5A and B). Low levels of Lif mRNA were detected in ovariectomized hamsters treated with oil. However, a single injection of estradiol- $17 \beta\left(E_{2}\right)$ rapidly increased the levels of Lif mRNA. The levels peaked at $2 \mathrm{~h}$, and gradually declined to basal levels by $24 \mathrm{~h}$ (Fig. 5B and C). A single injection of $\mathrm{P}_{4}$ alone had little effect on Lif mRNA expression except at $24 \mathrm{~h}$ (Fig. 5A and C).

Since $1 \mu \mathrm{g} \mathrm{E}_{2}$ stimulated Lif expression in Northern blot hybridization by $2 \mathrm{~h}$, we next determined the minimum dose of $E_{2}$ required to stimulate the uterine Lif expression by in situ hybridization. We treated 

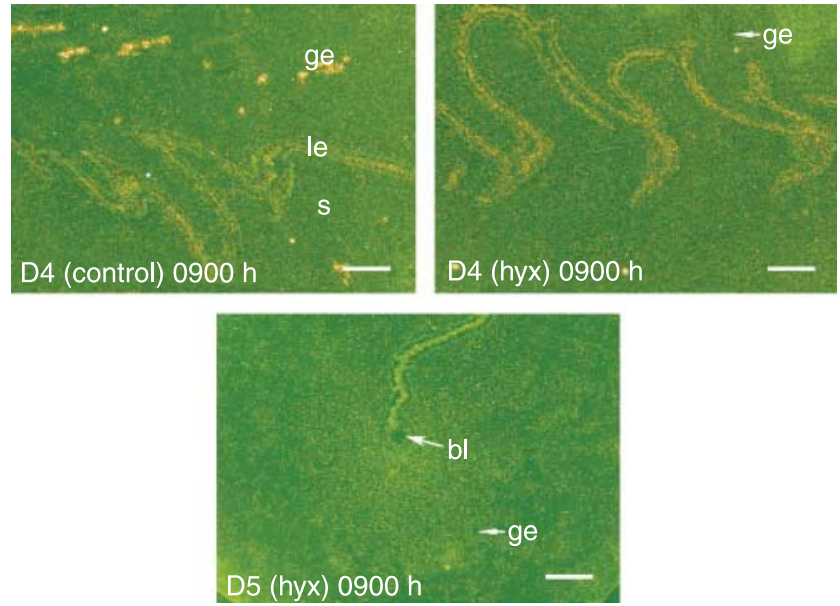

Figure 4 In situ hybridization of Lif mRNA in hypophysectomized (hyx) progesterone-treated pregnant (days 4 and 5) hamster uterus. Whole uterine tissues were collected on the morning of day $4(0900 \mathrm{~h})$. Implantation sites were collected on the morning of day $5(0900 \mathrm{~h})$ after an i.v. injection of blue dye as described in the Materials and Methods. Day 5 implantation sites obtained from sham operated pregnant hamsters treated with oil were used as negative control. Uterine sections were cut either longitudinally (day 4) or in cross (day 5). Bar $=250 \mu \mathrm{m}$. D4, day 4; D5, day 5; bl, blastocyst; ge, glandular epithelium; le, luminal epithelium; s, stroma.

ovariectomized hamsters with three different doses of $E_{2}$ $(0.01,0.10$, and $1.00 \mu \mathrm{g} /$ hamster) and observed that, while the lower doses of $E_{2}$ were unable to induce uterine Lif, the highest dose $(1 \mu \mathrm{g})$ clearly stimulated epithelial Lif expression by $2 \mathrm{~h}$ as compared with the oil-treated control uterus (Fig. 6). Next, we examined whether estrogen and progesterone and their combinations differentially regulate cell type-specific expression of Lif in the adult ovariectomized hamster. Uterine Lif expression in the luminal epithelium was upregulated by $E_{2}$ as compared with the oil-treated control at $2 \mathrm{~h}$ followed by a gradual decrease by $24 \mathrm{~h}$ (Fig. 7). The expression of Lif mRNA was not seen in the glandular epithelium at any time point after an injection of $\mathrm{E}_{2}$. Lif mRNA expression was not observed in any cell type after an injection of $\mathrm{P}_{4}$ even at $24 \mathrm{~h}$ (data not shown). However, uterine induction of Lif mRNA was noted both in the glandular and the luminal epithelia when ovariectomized animals received $\mathrm{E}_{2}$ in $\mathrm{P}_{4}$-primed uterus (Fig. 8).

\section{Cell type-specific expression of Lif receptor (Lif-r and gp130) $m R N A s$ in periimplantation uteri}

With respect to cell type-specific Lif-receptor expression, we noticed no clear expression of Lif-r (Fig. 9) and gp130 (Fig. 10) in any uterine cell types on days 1 and 2 of pregnancy. Lif-r started to appear in the luminal epithelium on day 3 and showed distinct accumulation in the luminal, but not in the glandular, epithelium on days 4 and 5 (Fig. 9). The expression of
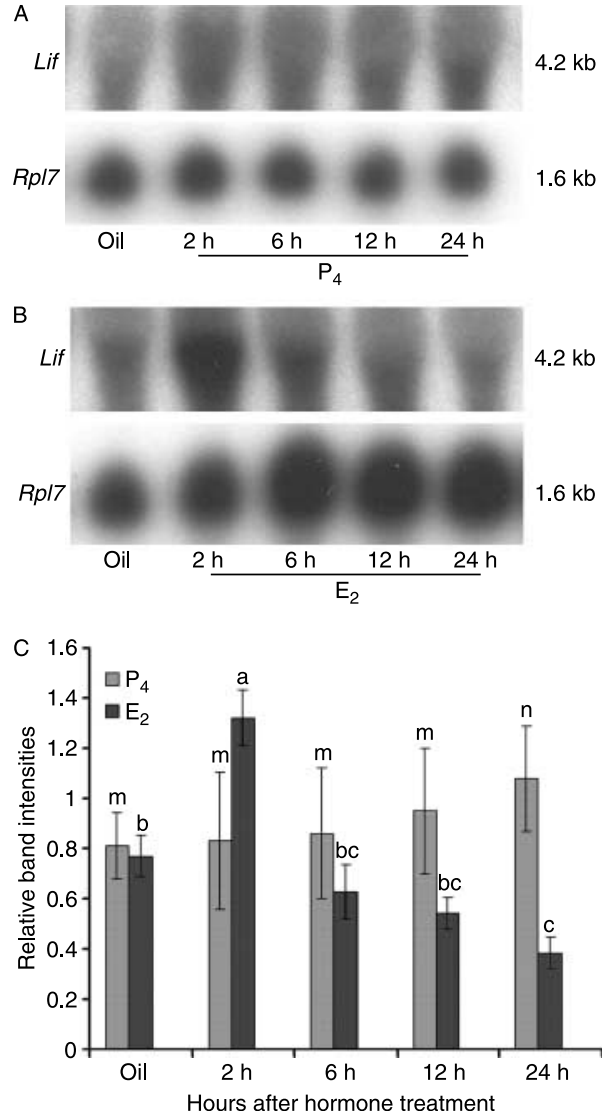

Figure 5 Northern blot analysis of uterine Lif mRNA in the uterus of ovariectomized hamsters treated with vehicle (sesame oil) or a single injection of $\mathrm{P}_{4}$ or $\mathrm{E}_{2}$. (A) Uterine Lif mRNA in the uterus of ovariectomized hamsters treated with $\mathrm{P}_{4}(1 \mathrm{mg} /$ hamster). (B) Uterine Lif mRNA in the uterus of ovariectomized hamsters treated with vehicle (sesame oil) or $E_{2}(1 \mu \mathrm{g} /$ hamster). (C) Bar diagram to show relative changes among normalized Lif band intensities (each Lif band intensity/corresponding Rp/7 band intensity). Vehicle-treated animals were killed at $2 \mathrm{~h}$. $\mathrm{E}_{2}$ - or $\mathrm{P}_{4}$-treated animals were killed at 2, 6, 12, and $24 \mathrm{~h}$. Total uterine RNA ( $6 \mu \mathrm{g} / \mathrm{lane})$ samples from each treatment group were separated by formaldehyde-agarose gel electrophoresis, transferred, and u.v. cross-linked to nylon membranes and hybridized sequentially to ${ }^{32} \mathrm{P}$-labeled Lif probes. The blot was also hybridized with Rpl7, a house keeping gene, to confirm integrity, loading, and blotting of RNA samples. Different letters over bars indicate significant differences $(P<0.05)$.

gp130 also started to appear on day 3, but its expression was not restricted to only the luminal epithelium; a low level of expression was also noticed in the glandular epithelium and stroma. While very low levels of gp130 mRNA persisted in stromal cells, its expression was clear and distinct in the epithelium of glands and lumen on days 4 to 5 (Fig. 10). With the progression of implantation on days 6-8, Lif-r and gp130 mRNAs mainly accumulated in the antimesometrial decidual cells adjacent to the implanting embryo. Lif-r expression was strong in the primary decidual zone (PDZ) of days 6 and 7 (Fig. 9). In contrast, the PDZ of day 6 implantation sites showed weak expression of gp130 but its 

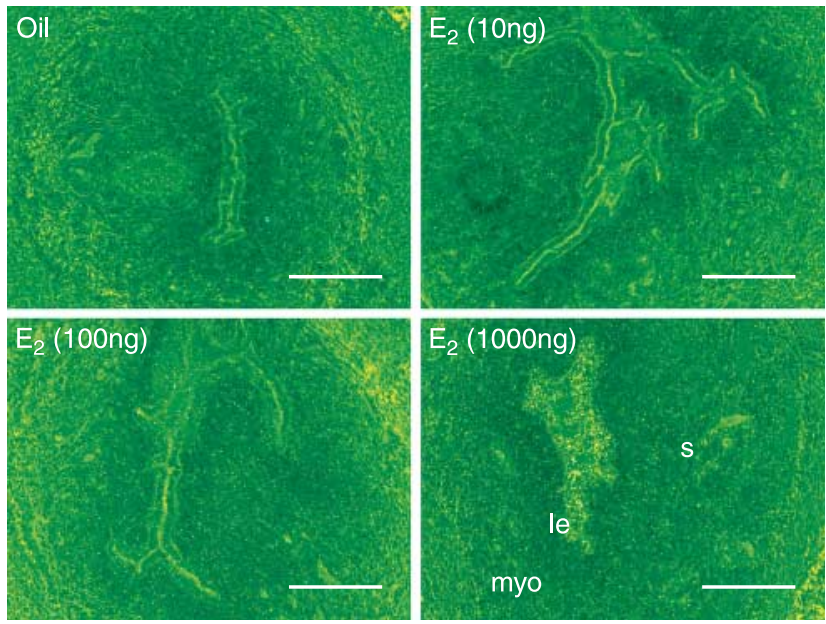

Figure 6 In situ hybridization of Lif mRNA in uteri of ovariectomized hamster after various doses of estradiol- $17 \beta$ treatment. Ovariectomized hamsters were killed $2 \mathrm{~h}$ after an injection of three doses of estradiol$17 \beta\left(\mathrm{E}_{2} ; 10,100\right.$, and $1000 \mathrm{ng} /$ hamster). Control ovariectomized hamsters that received an injection of oil were killed $2 \mathrm{~h}$ later. Bar $=200 \mu \mathrm{m}$. le, luminal epithelium; myo, myometrium; s, stroma.

expression was stronger on day 7 (Fig. 10). Particularly on day 8 , both the Lif-r and the gp130 showed almost comparable levels of expression, but their expression also extended to the mesometrial bed of the implantation site (Figs 9 and 10). Embryonic cells showed only a basal level of expression of Lif-r and gp130 mRNAs by in situ hybridization.

\section{Expression of Lif-r and gp130 mRNAs in the implantation site is not regulated by the presence of blastocysts}

Since Lif-r and gp130 mRNAs were both expressed in the PDZ area of the implantation site of hamsters, we explored the possibility of regulation of these genes by the implanting blastocyst. In situ hybridization studies using uterine sections obtained from day 6 decidual areas induced by either the blastocyst or the suture, demonstrated the presence of mRNAs of both Lif-r and gp130 in decidual areas induced by both methods (Fig. 11). These results suggest that decidual expression of Lif-r and gp130 mRNAs was not unique to the blastocyst stimulus and was mimicked by a physical stimulus.

\section{Hormonal regulation of uterine Lif-r and gp130 mRNA expression}

To examine whether ovarian steroids influence the induction of uterine Lif receptors, Lif-r and gp130 mRNA expressions in the uterus were examined by in situ hybridization on uterine sections obtained from ovariectomized mice treated with either oil, $E_{2}, P_{4}$, or a combination of $\mathrm{P}_{4}$ and $\mathrm{E}_{2}$. The results indicated that the expression of both Lif-r (Fig. 12) and gp130 (Fig. 13) in the uterine epithelium was induced by $P_{4}$, but not by $E_{2}$ (data not shown). The induction of Lif- $r$ mRNA by $\mathrm{P}_{4}$ was maximal in the uterine luminal and glandular epithelia by $2 \mathrm{~h}$ of $\mathrm{P}_{4}$ injection as compared with oil-treated controls. The $\mathrm{P}_{4}$-induced Lif-r mRNA levels were decreased by $6 \mathrm{~h}$ and remained at the same level until $24 \mathrm{~h}$ (Fig. 12). However, the same dose of $\mathrm{P}_{4}$ treatment showed only modest but gradual upregulation of gp130 mainly in the luminal epithelium (Fig. 13). When $\mathrm{P}_{4}$ and $\mathrm{E}_{2}$ were given together, Lif-r and gp130 mRNA expressions were noticed only in the luminal epithelial cells.

\section{Effect of a Lif antibody on implantation}

Five pregnant hamsters were injected with $2.4 \mu \mathrm{g} / 12 \mu \mathrm{l}$ Lif antibody in one uterine horn. The contralateral horn of these hamsters received an equal amount of goat $\lg \mathrm{G}$ $(2.4 \mu \mathrm{g} / 12 \mu \mathrm{l})$. When compared with IgG-treated control
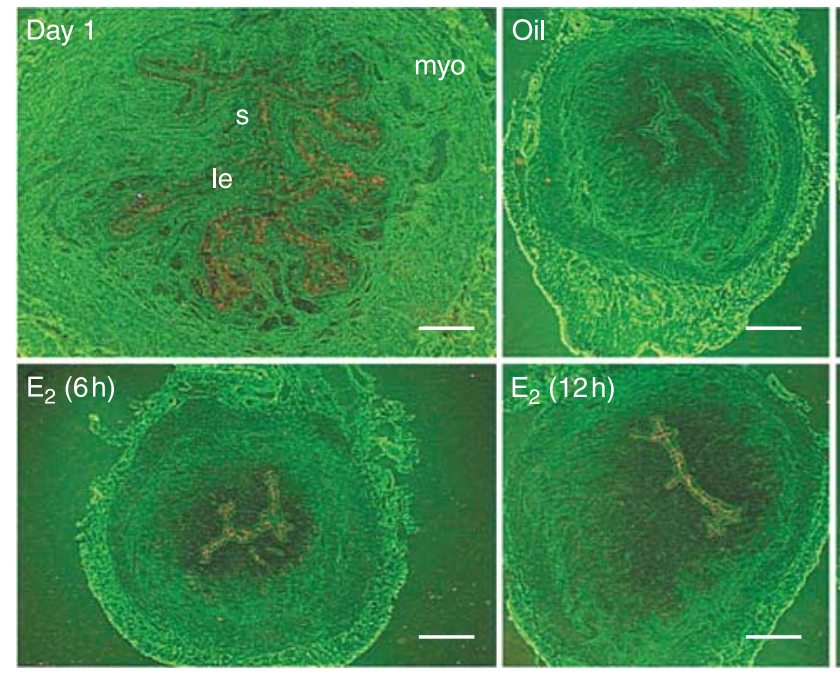
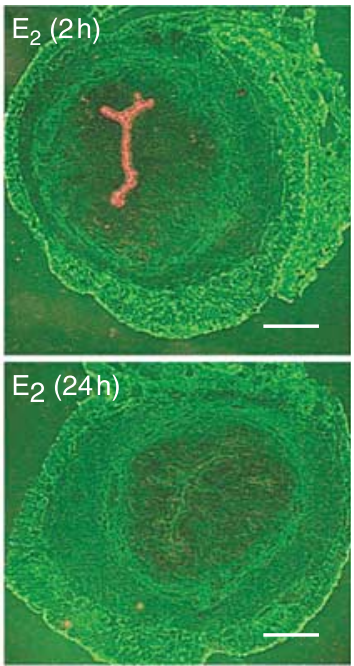

Figure 7 Cross-sections of ovariectomized hamster uteri treated with vehicle (sesame oil) or a single injection of estradiol- $17 \beta$ $\left(E_{2} ; 1000 \mathrm{ng} /\right.$ hamster) were processed for in situ hybridization to demonstrate cellspecific Lif mRNA expression. Vehicletreated animals were killed at $2 \mathrm{~h}$. $\mathrm{E}_{2^{-}}$ treated animals were killed at 2, 6, 12, and $24 \mathrm{~h}$. Sections from day 1 uterus were used as controls. Bar $=250 \mu \mathrm{m}$. le, luminal epithelium; myo, myometrium; s, stroma. 

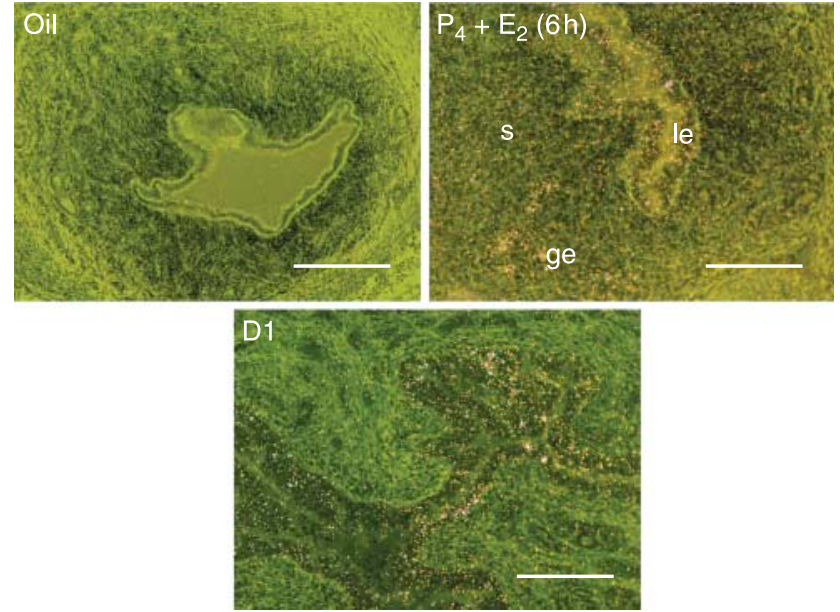

Figure 8 Cross-sections of ovariectomized hamster uteri treated with vehicle (sesame oil) or a combination of $\mathrm{P}_{4}\left(1 \mathrm{mg} /\right.$ hamster) and $\mathrm{E}_{2}$ (1000 ng/hamster) were processed for in situ hybridization to demonstrate cell-specific Lif mRNA. Animals treated with vehicle or $\mathrm{P}_{4}$ for 2 days and a combination of $\mathrm{P}_{4}$ and $\mathrm{E}_{2}$ on the third day were killed at $6 \mathrm{~h}$ after the last hormone injection. Bar $=200 \mu \mathrm{m}$. Sections from day 1 uterus were used as controls. ge, glandular epithelium; le, luminal epithelium; s, stroma.

horns, horns which received Lif antibody showed significant $(P<0.05)$ reduction in the number of implantation sites (Fig. 14A and B) on day 5. These results demonstrate an involvement of Lif during the process of implantation in hamsters.

\section{Discussion}

In this study, the importance of the Lif ligand-receptor signaling system for preparatory changes of the uterus for receptivity and implantation was investigated in hamsters. The clear expression of Lif, Lif-r, and gp130 in the uterine luminal epithelium on days 3 and 4 suggests that the luminal epithelium is the main target of uterine Lif action during the preparatory phase of the uterus for implantation. Our results also provide a view that uterine Lif is a conserved molecule during the time of uterine receptivity in mice and hamsters irrespective of their differences in ovarian hormonal requirements for implantation. In addition, the decidual expression of Lif receptors, but not Lif, at the site of implantation from days 6 to 8 of pregnancy suggests the potential role of circulating Lif at the site of decidualization. Our results also demonstrate here that, while Lif is most likely regulated by $\mathrm{E}_{2}$, Lif-r and gp130 are regulated by $\mathrm{P}_{4}$, but not by $E_{2}$, in the hamster.

During the preimplantation period, the expression of Lif in the luminal epithelium of the day 1 pregnant uterus could be attributed to the effects of preovulatory ovarian E secretion (Baranczuk \& Greenwald 1973). This is consistent with the induction of $L$ if in the uterine luminal epithelium in ovariectomized hamsters after an $E_{2}$ injection. On days 3 and 4 of pregnancy, low levels of Lif expression were observed in the luminal epithelium. This is consistent with the gradual increase in the levels of circulating estrogen from day 2 of pregnancy in hamsters (Leavitt \& Blaha 1970, Baranczuk \& Greenwald 1974). However, Lif expression was much more prominent in the glandular epithelium on day 4 as compared with the luminal epithelium. This glandular Lif expression on day 4 could be due to either the combined effect of ovarian $\mathrm{P}_{4}$ and $\mathrm{E}_{2}$ or the presence of an embryo inside the uterus on these days. Indeed, Lif expression in the glandular epithelium was induced, albeit at low levels, by a combined treatment of $\mathrm{P}_{4}$ and $\mathrm{E}_{2}$ in ovariectomized hamsters, suggesting a possible
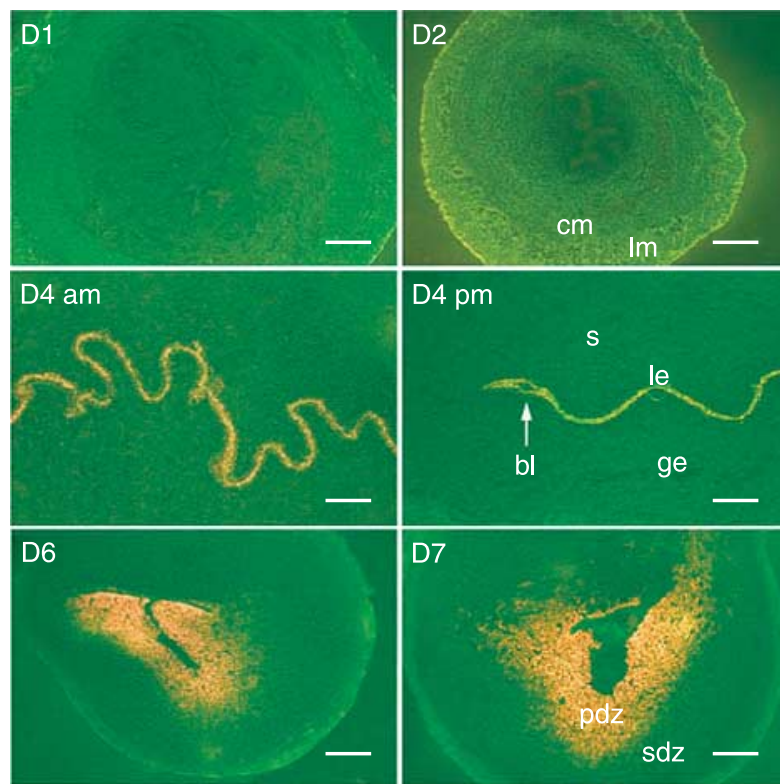

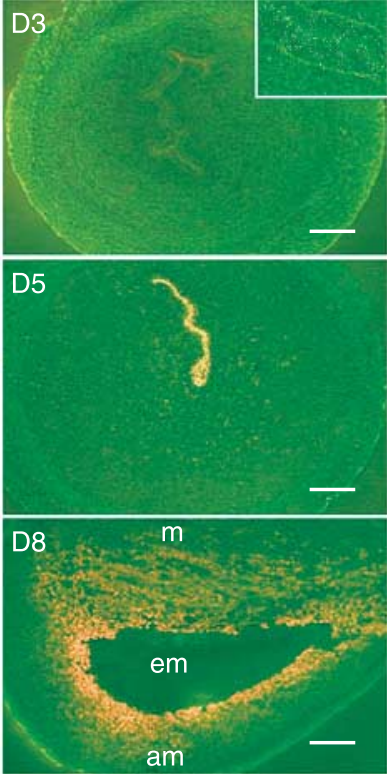

Figure 9 Sections of hamster uteri from days 1 to 8 (D1-D8) of pregnancy were processed for in situ hybridization to demonstrate cellspecific Lif-r mRNA expression. Day 4 uterine sections were taken longitudinally. Bar $=250 \mu \mathrm{m}$. am, antimesometrial side; bl, blastocyst; cm, circular muscle; D4 am, Day 40900 h; D4 pm, Day 41600 h; em, embryo; ge, glandular epithelium; le, luminal epithelium; Im, longitudinal muscle; $\mathrm{m}$, mesometrial side; pdz, primary decidual zone; s, stroma; sdz, secondary decidual zone. 

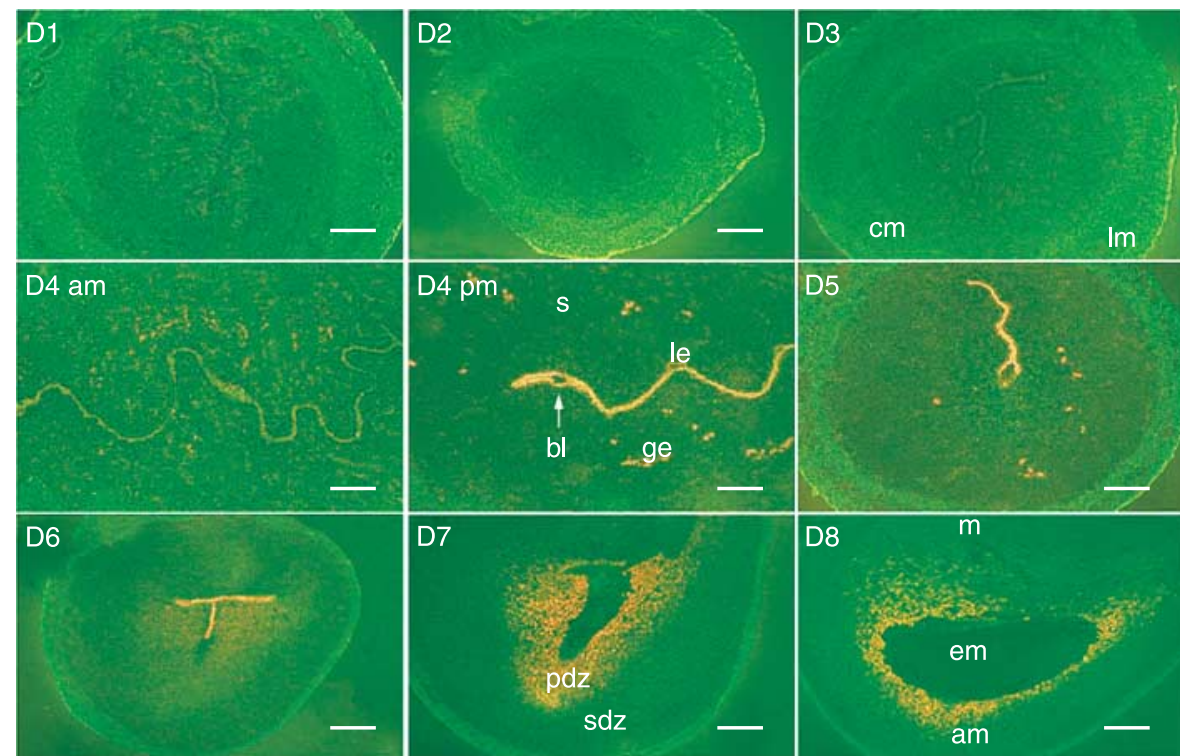

Figure 10 Sections of hamster uteri from days 1 to 8 of pregnancy were processed for in situ hybridization to demonstrate cell-specific gp130 mRNA expression. Day 4 uterine sections were taken longitudinally. Bar $=250 \mu \mathrm{m}$. am, antimesometrial side; bl, blastocyst; $\mathrm{cm}$, circular muscle; D4 am, Day 40900 h; D4 pm, Day 41600 h; em, embryo; ge, glandular epithelium; le, luminal epithelium; Im, longitudinal muscle; $\mathrm{m}$, mesometrial side; pdz, primary decidual zone; s, stroma; sdz, secondary decidual zone. mutual effect of steroids on glandular Lif expression. However, when day 4 uterine sections from the $\mathrm{P}_{4^{-}}$ treated hypophysectomized hamsters were processed for in situ hybridization to locate Lif expression, we observed its accumulation only in the luminal, but not in the glandular, epithelial cells. These results suggest that in the absence of circulating estrogen, the presence of an embryo inside the uterus can also induce an Lif mRNA expression that is restricted to the luminal epithelium. Since developing embryos enter into the uterus on day 3 of pregnancy in hamsters (Wang et al. 2002), an accumulation of Lif in the luminal epithelium could be influenced by the presence of embryos inside the uterus. The identification of this embryonic factor(s) remains a challenging question. There is evidence that the embryo of certain species including hamsters have the capacity to produce estrogen (Perry et al. 1973,
Dickmann et al. 1976, George \& Wilson 1978, Heap et al. 1981, Hoversland et al. 1982, Sholl et al. 1983). We have preliminary evidence that hamster preimplantation embryos express the aromatase protein (unpublished observation). Since (1) Lif is an important maternal factor for implantation (Stewart et al. 1992), (2) the uterine luminal epithelium expresses Lif during the time of uterine receptivity, and (3) normal implantation occurs in $\mathrm{P}_{4}$-treated hypophysectomized hamsters (Prasad et al. 1960), it is possible that the embryo plays a critical role in regulating the uterine environment during the time of implantation in hamsters. Furthermore, normal blastocyst implantation in $\mathrm{P}_{4}$-treated hypophysectomized hamsters also suggests that luminal epithelial Lif expression could be adequate to initiate the process of implantation in this species. Since both Lif-r and gp130 were expressed in the luminal epithelium on
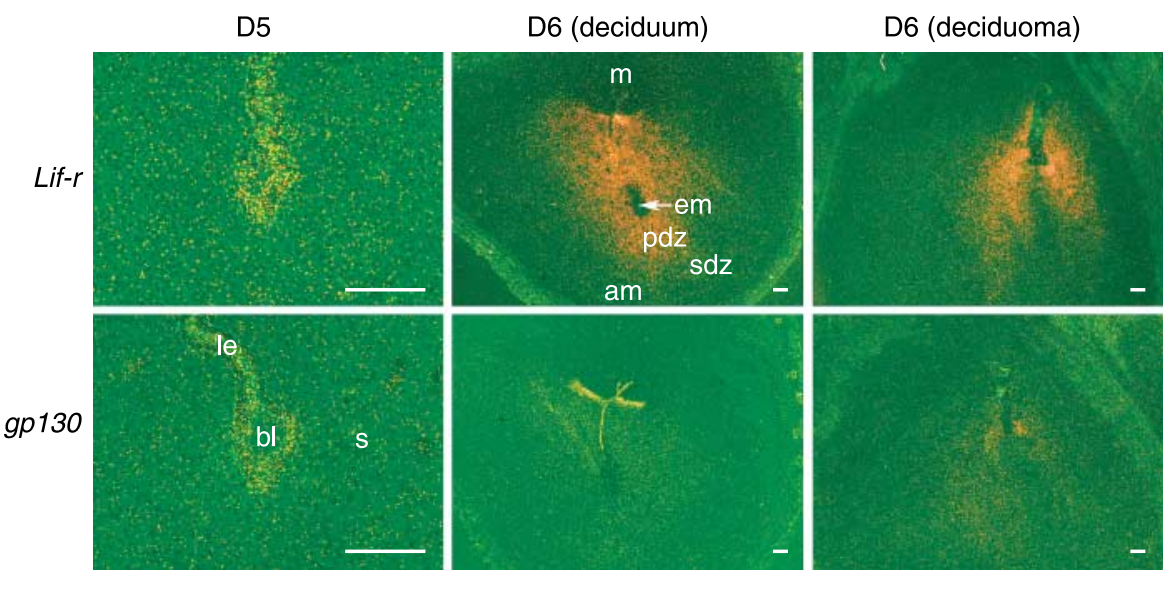

Figure 11 Cross-sections of hamster day 6 blastocyst-induced deciduum and sutureinduced deciduoma were processed for in situ hybridization to demonstrate cellspecific expression of Lif-r and gp130. Sections from day 5 implantation site were used as controls. Bar $=200 \mu \mathrm{m}$. am, antimesometrial side; bl, blastocyst; em, embryo; le, luminal epithelium; $\mathrm{m}$, mesometrial side; $\mathrm{pdz}$, primary decidual zone; s, stroma; sdz, secondary decidual zone. 

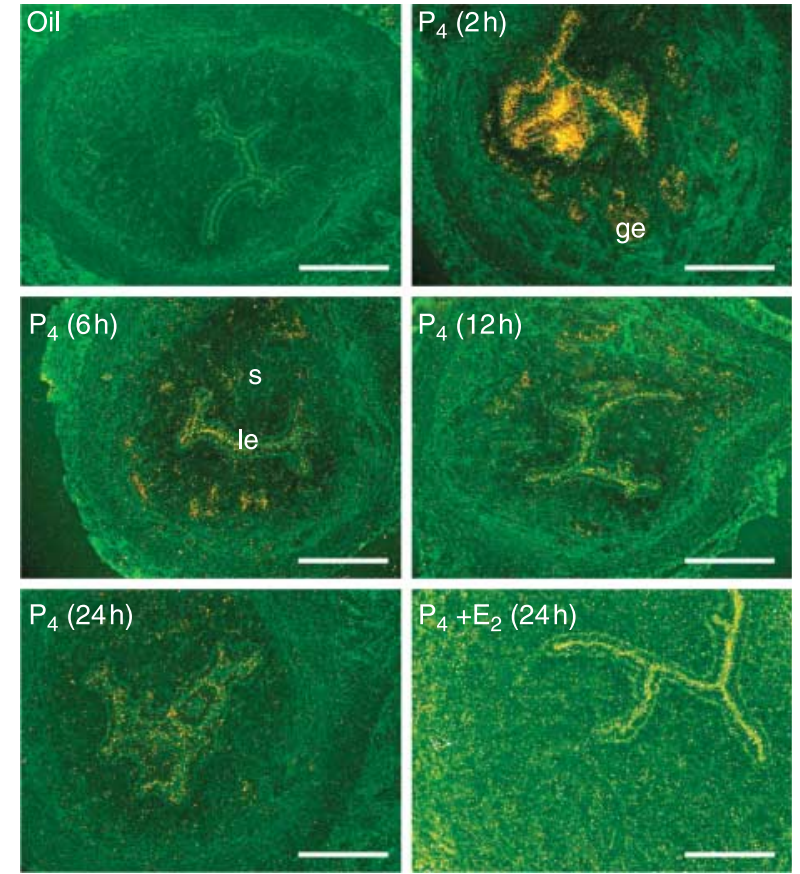

Figure 12 Cross-sections of ovariectomized hamster uteri treated with vehicle (sesame oil) or a single injection of progesterone $\left(\mathrm{P}_{4}\right.$; $1 \mathrm{mg} /$ hamster $)$ or progesterone ( $\mathrm{P}_{4} ; 1 \mathrm{mg} /$ hamster) plus estradiol-17 $\beta$ $\left(\mathrm{E}_{2} ; 1 \mu \mathrm{g}\right.$ /hamster) were processed for in situ hybridization to demonstrate cell-specific Lif- $r$ mRNA expression. Vehicle-treated animals were killed at $2 \mathrm{~h}$. $\mathrm{P}_{4}$-treated animals were killed at 2, 6, 12, and $24 \mathrm{~h}$. Bar $=200 \mu \mathrm{m}$. le, luminal epithelium; ge, glandular epithelium; s, stroma.

days 3 and 4 of pregnancy, Lif action on luminal epithelium is likely to be important for uterine receptivity and implantation. The specific purpose and function of Lif accumulation in the glandular epithelium on day 4 of pregnancy remains to be determined.

The importance of uterine Lif in the implantation process has been confirmed in mice by a gene knockout study (Stewart et al. 1992). The uterine expression pattern of Lif around the time of implantation in mice suggests that Lif may play dual functions in initiating implantation, first in the preparation of a receptive uterus and subsequently in the attachment reaction (Song et al. 2000). Lif mRNA expression in the gland as well as in the luminal epithelium prior to implantation in hamsters suggests its possible role during preparation of the receptive uterus. However, the absence of Lif expression in stromal cells surrounding the implanting embryo on the afternoon of day 4 and onwards indicates that stromal production of Lif is not necessary for uterine changes associated with implantation such as stromal cell proliferation and differentiation. This discrepancy between mice and hamsters could possibly be attributed to differences in hormonal regulation of implantation between these two rodents. We next studied the importance of Lif in implantation by neutralizing intrauterine Lif using an
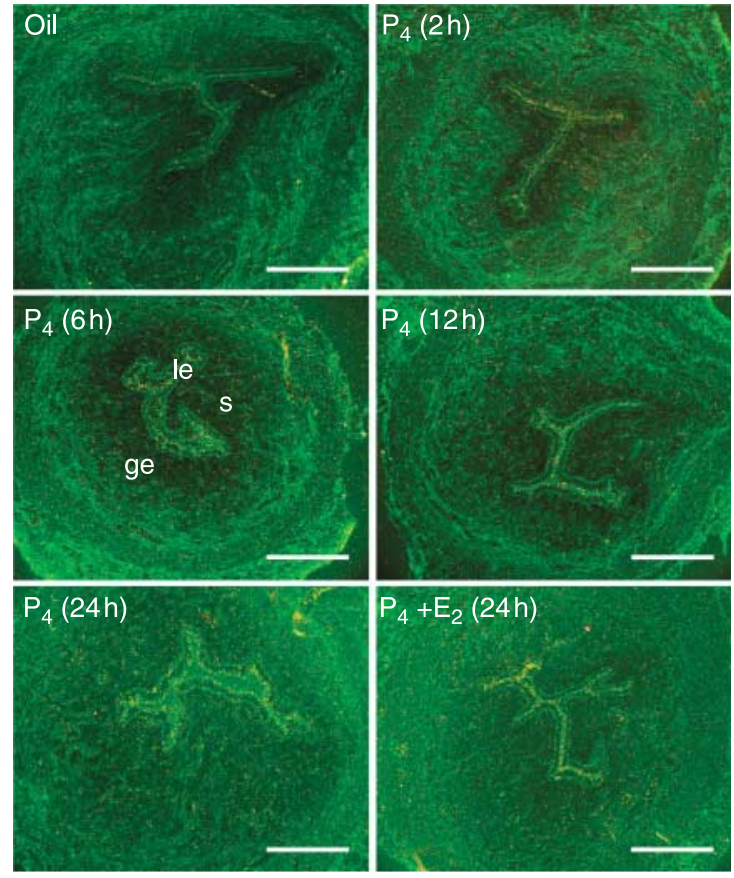

Figure 13 Cross-sections of ovariectomized hamster uteri treated with vehicle (sesame oil) or a single injection of progesterone $\left(\mathrm{P}_{4}\right.$; $1 \mathrm{mg} /$ hamster $)$ or progesterone ( $\mathrm{P}_{4} ; 1 \mathrm{mg} /$ hamster) plus estradiol-17 $\beta$ $\left(\mathrm{E}_{2} ; 1 \mu \mathrm{g}\right.$ /hamster) were processed for in situ hybridization to demonstrate cell-specific gp130 mRNA expression. Vehicle-treated animals were killed at $2 \mathrm{~h}$. $\mathrm{P}_{4}$-treated animals were killed at 2, 6, 12, and $24 \mathrm{~h}$. Bar $=200 \mu \mathrm{m}$. le, luminal epithelium; ge, glandular epithelium; s, stroma.

antibody of Lif. These results showed that intraluminal injection of a Lif antibody partially prevented implantation suggesting an important role of Lif during the time of implantation in hamsters.

$$
\text { A }
$$

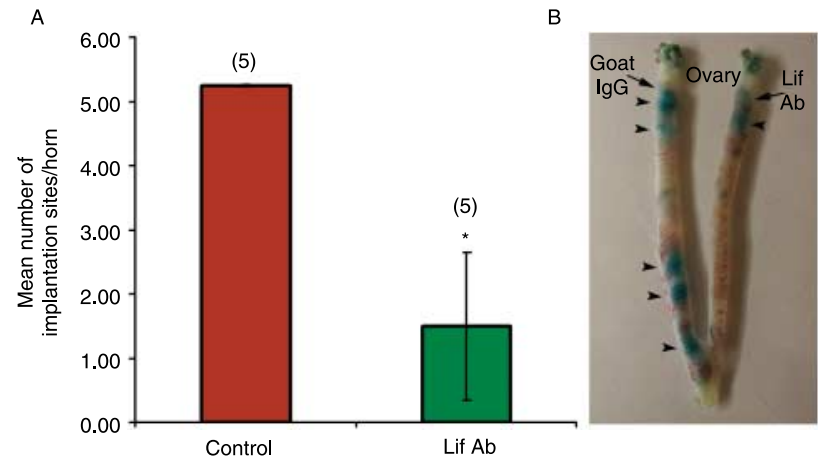

Figure 14 An intraluminal application of Lif antibody has partially inhibited implantation in pregnant hamsters. (A) Bar diagram showing the mean number of implantation sites in each uterine horn. (B) Representative uterine horns from one out of the five hamsters. Pregnant hamsters received a single intraluminal injection of Lif antibody ( $\mathrm{Lif} \mathrm{Ab}$ ) in one uterine horn and goat IgG (control) in the contralateral horn on day 3 of pregnancy when embryos were still inside the oviducts. Implantation sites were determined by blue dye injection on day 5 at $0900 \mathrm{~h}$. Number in parentheses indicates the number of uterine horns. Arrowheads indicate the location of implantation sites. ${ }^{*} P<0.05$ (Student's $t$-test). 
Preimplantation embryos themselves express certain cytokines or growth factors and their receptors. Several studies have reported that $L$ if and Lif- $r$ are expressed in preimplantation blastocysts of mice and humans (Conquest \& Brulet 1990, Murray et al. 1990, Sharkey et al. 1995, Nichols et al. 1996, Chen et al. 1999). Since Lif and Lif-r are also expressed in the uterus of these species, both an autocrine and a paracrine role of Lif in embryogenesis have been suggested. Exogenous Lif increases the number of human embryos developing to the blastocyst stage in vitro (Dunglison et al. 1996). A contradictory result also exists demonstrating that supplementing culture medium with Lif does not improve human blastocyst formation (Jurisicova et al. 1995). However, Lif is not critical to the formation of mouse blastocysts because fertilized Lif $(-/-)$, Lif-r (-/-), and gp130 (-/-) embryos can develop normally to the blastocyst stage and implant (Stewart et al. 1992, Ware et al. 1995, Yoshida et al. 1996). Since Lif, Lif-r, and gp130 expression patterns in the preimplantation embryos of hamsters are unknown, whether or not Lif produced by the uterus can interact with the embryo is unknown at this point.

The Lif-r-gp130 heterodimer is implicated in diverse functions of Lif in many processes including blastocyst implantation in mice (Song \& Lim 2006). In our study, Lif-r and gp130 signals were clearly detected in the luminal epithelium on days 4 and 5 of pregnancy in hamsters. This suggests that the uterine luminal epithelium may be the main target of uterine Lif action because the expression of both the receptors in this uterine cell type. After the initiation of implantation, however, both Lif-r and gp130, but not their ligand, were expressed in decidual cells surrounding the implanting embryo. This pattern of uterine Lif-r and gp130 localization around the time of implantation was very similar to that reported in the mouse (Cheng et al. 2001, 2002, Ni et al. 2002), human (Cullinan et al. 1996), and monkey (Yue et al. 2000). The co-localization of Lif-r and gp130 in periimplantation decidual cells suggests that Lif action is important for decidualization. Since Lif was not expressed in decidual cells of hamsters, we suggest a possible role for circulating Lif on decidual cells. Contrary to this finding in hamsters, Lif expression in decidual cells and its regulation by decidual cytokines and $E_{2}$ has been reported in humans (Kojima et al. 1994, Sawai et al. 1995, 1997). It is also possible that other members of the IL-6-type cytokine family that share the use of glycoprotein gp130 may be involved in decidualization. These cytokines are IL-6 itself, IL-11, oncostatin $M$, ciliary neurotrophic factor, and cardiotropin-1 (Gearing et al. 1992). It has been reported that IL-11 receptor $\alpha$-null mice were infertile due to defective post-implantation decidua formation at the implantation site (Robb et al. 1998). Both IL-11 and IL-11 receptor $\alpha$ are highly expressed in the decidua on days 6-9 of pregnancy (Bilinski et al. 1998, Robb et al. 1998). Similar temporal and spatial pattern of IL-11 and IL-11 receptor $\alpha$ was observed in the periimplantation rat uterus ( $\mathrm{Li}$ et al. 2001). Since gp130 is required for IL-11 receptor $\alpha$ to bind IL-11 with high affinity (Hilton et al. 1994), its expression in decidual cells is important for implantation.

The expression of Lif-r and gp130 on days 3 and 4 of pregnancy suggests possible hormonal regulation of these genes in the uterus. In this regard, it has been demonstrated in mice that, while $\mathrm{P}_{4}$ or $\mathrm{E}_{2}$ alone was not effective in stimulating Lif-r and gp130 mRNAs in the ovariectomized animal, a combination of these steroids did stimulate the expression of these genes in the uterine epithelium ( $\mathrm{Ni}$ et al. 2002). Recently, another study has demonstrated E-induced Lif-r expression in the trabecular bone (Lindberg et al. 2002). Using immunocytochemical localization of proteins, several studies have demonstrated in the human and monkey uterus that Lif-r and gp130 localization during the luteal phase were stronger than their localization during the proliferative phase (Yue et al. 2000, Classen-linke et al. 2004). The most intense immunostaining of IL-11 was also seen in decidualized stromal cells in the mid- and late-secretory phases in human uterus (Dimistriadis et al. 2000). This strong expression of Lif-r, gp130, and IL-11 during the luteal phase coincided with the period of uterine receptivity, stromal cell decidualization, and increasing levels of maternal $\mathrm{P}_{4}$ during this period, suggesting the possibility that expression of these molecules in the monkey and human uterus may be regulated by $\mathrm{P}_{4}$. In this study, for the first time, we report that Lif-r and gp130 are most likely regulated by $P_{4}$, but not $E_{2}$, in the ovariectomized hamster uterus. $E_{2}$ also had no additive effects on the expression of these two genes when $\mathrm{P}_{4}$ and $E_{2}$ were given together.

Embryo-uterine interaction during the initiation of implantation is a multi-event cascade involving cellspecific alterations in the expression of various genes. The identification of such genes and evaluation of the consequences of their altered expression is essential for attempts to halt implantation or to correct implantation problems to improve the rate of pregnancy. One critical problem to be considered in evaluating such genes is the differences between species. In this study, the preimplantation expression pattern and hormonal regulation of uterine Lif in hamsters were generally similar to mice. However, the Lif expression pattern during the time of embryo-uterine attachment reaction in hamsters was different from that in mouse. Thus, it is more likely that there is an intrinsic difference between mice and hamsters in the expression of Lif. In conclusion, although differences in hormonal requirements for uterine receptivity and initiation of implantation across species exist, the temporal specificity of epithelial Lif expression before implantation is a requirement for the preparation of the receptive uterus for initiation of maternal-embryo interactions for implantation. 


\section{Materials and Methods}

\section{Animal and tissue preparation}

Adult virgin male and female golden hamsters (Mesocricetus auratus) and CD1 mice were purchased from Charles River Laboratory, Raleigh, NC, USA. They were housed on a $12 \mathrm{~h}$ light:12 h darkness cycle and fed commercial chow ad libitum. All surgical procedures and the killing of the animals were approved by the appropriate Institutional Animal Care and Use Committee. Female hamsters that showed three consecutive estrous cycles were placed with fertile males on the evening of the proestrous day for mating. Microscopic finding of spermatozoa in the vaginal discharge the next morning was designated day 1 of pregnancy (Wang et al. 2002, 2004, Zhang $\&$ Paria 2006). Female mice were mated with fertile male to induce pregnancy (day 1 of pregnancy $=$ vaginal plug; Paria et al. 1993, Zhang \& Paria 2006). Hamsters and mice on days 1-3 were killed between 0830 and $0900 \mathrm{~h}$, and whole uteri were flash-frozen. Pregnancy on these days was confirmed by recovering embryos from oviducts. Whole pregnant uteri of hamsters and mice were collected on the morning of day 4 (0900 h) without flushing. Implantation sites from the pregnant hamsters on the afternoon $(1600 \mathrm{~h})$ of day 4 and the morning $(0900 \mathrm{~h})$ of days 5 and 6 were collected $15 \mathrm{~min}$ after an i.v. injection of Chicago Blue B dye solution $(0.25 \mathrm{ml}$ of $1 \%$ dye in saline). Implantation sites from the pregnant mice on the morning $(0900 \mathrm{~h})$ of day 5 were collected $5 \mathrm{~min}$ after an i.v. injection of Chicago Blue B dye solution $(0.10 \mathrm{ml}$ of $1 \%$ dye in saline). On days 6-8, implantation sites are distinct and their identification does not require blue dye injection. Uterine tissues were immediately flash-frozen for extraction of total RNA later or for use in in situ hybridization experiments (Paria et al. 1993, Wang et al. 2002, 2004).

Implantation occurs without delay in hamsters ovariectomized or hypophysectomized on day 2 of pregnancy and given $\mathrm{P}_{4}$ daily (Prasad et al. 1960, Harper et al. 1969, Wang et al. 2002, 2004). Thus, to address the issue of the regulation of implantation-specific gene expression by either $\mathrm{P}_{4}$, blastocysts or both, a group of pregnant hamsters were either hypophysectomized or ovariectomized on day 2 (0900 h). Hypophysectomized hamsters were given $\mathrm{P}_{4}$ subcutaneously (Sigma Chemical Company; $1 \mathrm{mg}$ in $0.1 \mathrm{ml}$ sesame seed oil/hamster) on days 2 and 3 of pregnancy. Control animals underwent sham operations and were injected with oil. Whole uteri were collected on day 4 morning ( $0900 \mathrm{~h}$ ) for Lif mRNA detection by in situ hybridization (Wang et al. 2002). Ovariectomized hamsters were given an s.c. injection of $\mathrm{P}_{4}$ on days $2,3,4$, and 5 to maintain pregnancy. A small piece of silk suture was threaded through the lumen of one uterine horn on day 3 of pregnancy to induce deciduoma experimentally in this horn. The contralateral horn of this animal remained intact for normal embryo-induced implantation and decidualization. Animals were killed on day 6 after an i.v. blue dye injection and the embryo-induced decidual and the suture-induced deciduomal tissues were collected separately. The expression of Lif-r and gp130 was compared between the decidual and the deciduomal tissues by in situ hybridization.

To determine the effects of steroids on uterine Lif, Lif-r, and gp130, female hamsters were ovariectomized and rested for
12 days (Zhang \& Paria 2006). One group of these hamsters received an s.c. injection of sesame oil $(0.2 \mathrm{ml} /$ hamster $)$ or $\mathrm{P}_{4}$ $(1 \mathrm{mg} / 0.2 \mathrm{ml}$ oil/hamster $)$ or $\mathrm{E}_{2}(1.0 \mu \mathrm{g} / 0.2 \mathrm{ml}$ oil/hamster $)$. Hamsters were killed at 2, 6, 12, and $24 \mathrm{~h}$ after injection of either $\mathrm{P}_{4}$ or $\mathrm{E}_{2}$. Animals treated with 2 days of $\mathrm{P}_{4}$ and $\mathrm{a}$ combination of $\mathrm{P}_{4}$ and $\mathrm{E}_{2}$ on day 3 were killed at $6 \mathrm{~h}$ after last injection. Their uteri were collected for RNA extraction and in situ hybridization. To determine the minimum amount of $E_{2}$ required for the induction of Lif expression, the second group of ovariectomized hamsters was given a single injection of 10 , 100, or $1000 \mathrm{ng} \mathrm{E}_{2}$. Animals in this group were killed at $2 \mathrm{~h}$ after an injection of $E_{2}$ and uteri were processed for in situ hybridization of Lif.

\section{Total RNA preparation}

Uterine RNA was extracted by applying TRIZOL reagent (Gibco Life Technologies). Briefly, tissues were homogenized in TRIZOL reagent ( $1 \mathrm{ml} / 50 \mathrm{mg}$ tissue) and mixed with $0.2 \mathrm{ml}$ chloroform/ml TRIZOL and centrifuged at $12000 \mathrm{~g}$ for $15 \mathrm{~min}$ at $4{ }^{\circ} \mathrm{C}$. The aqueous phase was measured, collected, and treated with isopropyl alcohol $(0.5 \mathrm{ml} / \mathrm{ml}$ TRIZOL reagent) for precipitation of RNA. After an incubation period of $10 \mathrm{~min}$ at room temperature, the samples were centrifuged at $12000 \mathrm{~g}$ for 10 min to precipitate the RNA. The precipitated RNA was suspended in $75 \%(\mathrm{v} / \mathrm{v})$ ethanol $(1 \mathrm{ml}$ of $75 \%$ ethanol $/ \mathrm{ml}$ of TRIZOL) and centrifuged at $7500 \mathrm{~g}$ for $5 \mathrm{~min}$ to reprecipitate RNA. At the end of the procedure, the RNA pellet was vacuum dried (Wang et al. 2002, 2004).

\section{Cloning of the hamster specific partial cDNAs for Lif, Lif-r, and gp130}

RT PCR was employed to generate the hamster-specific cDNA clones for Lif, Lif-r, and gp130. The published sequences used to design the primers were of mouse origin. The primers were: Lif (GenBank accession number AF065918, spanning nucleotides 40-390; size 351, 5'-CTGGTTCTGCACTGGAAACA-3' (sense) and 5'-AGTGGGGTTCAGGACCTTCT-3' (antisense)); gp130 (GenBank accession number NM_010560, spanning nucleotides 1015-1476, size 462, 5'-ACAGCTGCAGCTGATTAGCC-3' (sense) and 5'-CAATATAGGACCAAAGATGC-3' (antisense)); and Lif-r (GeneBank accession number NM_013584, spanning nucleotides 2077-2446, size 370, 5'-GGAGAAAGGTTCCTTCAAAC-3' (sense) and 5'-TCTCAGTGTCTTCTGGGATA-3' (antisense)). The uterine total RNA ( $1 \mu \mathrm{g})$ from day 4 pregnant hamster was reverse-transcribed in a total volume of $20 \mu \mathrm{l}$ using antisense primer. RT products $(3 \mu \mathrm{l})$ were amplified by PCR for 35 cycles using the following cycle parameters: $94{ }^{\circ} \mathrm{C}, 45 \mathrm{~s} ; 55^{\circ} \mathrm{C}, 30 \mathrm{~s}$; $72{ }^{\circ} \mathrm{C}, 1 \mathrm{~min} 30 \mathrm{~s}$. The RT-PCR products were cloned into a pCR-II-TOPO cloning vector (3.9 kb) using TOPO TA Cloning kit, Version K2 (Invitrogen Corporation) and nucleotide sequences of the clone were determined to verify the identity and orientation of the clones. The GenBank accession numbers for the resulting hamster Lif, Lif-r, and gp130 cDNA fragments are AF327897, AF492475, and EF442778 respectively. Nucleotide sequences of these partial cDNA clones showed more than $80 \%$ sequence similarities with those of the GenBank nucleotide database for rats, mice, and humans. 


\section{RNA probe preparation}

Plasmids bearing hamster cDNA were exacted, purified, and linearized (Lif: T7/HindIII for antisense, SP6/Notl for sense; Lif-r: T7/BamHI for antisense, SP6/Xhol for sense; gp130: SP6/Xhol for antisense, T7/HindIII for sense) to generate antisense and sense riboprobes, which were transcribed using appropriate RNA polymerases and labeled with either ${ }^{32} \mathrm{P}$ or ${ }^{35} \mathrm{~S}$ for Northern or in situ hybridizations respectively. A partial clone of mouse Rpl7 cDNA was also used as a template for synthesis of ${ }^{32} \mathrm{P}$-labeled antisense cRNA probe with T7 polymerase. All labeled sense and antisense cRNA probes used for hybridizations had specific activities of $\sim 2 \times 10^{9} \mathrm{dpm} / \mu \mathrm{g}$ (Wang et al. 2002, 2004).

\section{Northern blot hybridization}

Total RNA ( $6 \mu \mathrm{g}$ ) was separated by formaldehyde-agarose gel electrophoresis, blotted to nitrocellulose membranes, and cross-linked to the membrane by u.v. irradiation. Membranes were prehybridized, hybridized, and washed as described previously (Wang et al. 2002, 2004). The blots were then hybridized with ${ }^{32} \mathrm{P}$-labeled Lif and Rp/7 probes, and the hybrids were detected by autoradiography. Each Northern blot hybridization experiment was repeated to ensure reproducibility of results. The optical density of each hybrid band was determined using the NIH Image J program (NIH, Bethesda, MD, USA). For normalization, the intensity of each band was divided by the value of the corresponding Rpl7 band intensity.

\section{In situ hybridization}

The protocol was followed as described previously by our group (Wang et al. 2002, 2004). Briefly, frozen uterine sections were mounted onto poly-L-lysine-coated slides and fixed in cold 4\% paraformaldehyde solution in PBS for 15 min on ice. After prehybridization, sections were hybridized to ${ }^{35} \mathrm{~S}$-labeled antisense probes at $45{ }^{\circ} \mathrm{C}$ for $4 \mathrm{~h}$ in $50 \%$ formamide hybridization buffer. Sections were also hybridized with ${ }^{35} \mathrm{~S}$ labeled sense probes as negative control. After hybridization and washing, sections were incubated with RNase A $(20 \mu \mathrm{g} / \mathrm{ml})$ at $37^{\circ} \mathrm{C}$ for $20 \mathrm{~min}$. RNase A resistant hybrids were detected by autoradiography using Kodak NTB-2 liquid emulsion (Eastman Kodak Company). The slides were then stained with hematoxylin and eosin. Because of the involvement of multiple variable steps in this lengthy process of in situ hybridization, quantitation of autoradiographic grains was not performed.

\section{Analysis of blastocyst implantation after intraluminal treatment of Lif antibody in pregnant hamsters}

The ability of the Lif antibody to inhibit implantation was determined in pregnant hamsters. An affinity-purified anti-Lif goat polyclonal antibody (Goat polyclonal IgG (M-19); cat. no. SC1767; Santa Cruz Biotechnology, Santa Cruz, CA, USA) was used in this study. Cross-reactivity of this anti-Lif antibody with hamster Lif was tested by Western blotting using day 4 hamster uterine tissues. Pregnant hamsters were anesthetized with avertin and an incision was made in each side of the lower back right above the ovarian fat pad. The ovarian end of each uterine horn was then exteriorized by pulling the ovarian fat pad out of the abdominal cavity. A single intraluminal injection of this Lif antibody $(2.4 \mu \mathrm{g} / 12 \mu \mathrm{l})$ was administered with a Hamilton glass syringe attached to a 31-gauge steel needle in one uterine horn close to the utero-tubal junction on the morning of day 3 when embryos were still in oviducts. The injection site was held shut after withdrawal of the needle for at least 20-30 s to minimize reflux. The contralateral horn received an intraluminal injection of an equal volume and concentration of Goat IgG (cat. no. F-7381; Sigma) that was purified from normal goat serum by ion exchange chromatography and is essentially free from other goat serum proteins. Hamsters were killed on the morning of day 5 (0900 h) $15 \mathrm{~min}$ after blue dye injection. The number of blue bands present in each horn was visually counted.

\section{Statistical analysis}

Each experiment was replicated three times. All quantitative Northern blot data are presented as the mean \pm s.E.M. To compare the difference in band intensities, results obtained in Northern blot hybridization experiments were subjected to statistical analysis (SAS 9.1 program from SAS Institute Inc., Cary, NC, USA) using one-way ANOVA. If overall ANOVA exhibited significant differences, then comparisons among groups were performed using Tukey's Studentized range test. For other experiments, the difference between two groups was analyzed by Student's $t$-test. $P<0.05$ was considered statistically significant.

\section{Acknowledgements}

We acknowledge the support from all members of the Division of Reproductive and Developmental Biology of the Department of Pediatrics. This work was supported by National Institutes of Health (NIH) grants (HD044741 and UO1 HD042636) to B C P. The support of the National Cooperative program on Trophoblast-Maternal Tissue Interactions is gratefully acknowledged. The authors would like to give special thanks to Dr S K Roy for providing uterine tissues from hypophysectomized pregnant hamsters. Our thanks to S K Dey and S K Das for allowing free access to their laboratories and Hehai Wang for statistical analysis. Dr H Song was a graduate student of Dr S K Dey. The authors declare that there is no conflict of interest that would prejudice the impartiality of this scientific work.

\section{References}

Baranczuk R \& Greenwald GS 1973 Peripheral levels of estrogen in the cyclic hamster. Endocrinology 92 805-812.

Baranczuk R \& Greenwald GS 1974 Plasma levels of estrogen and progesterone in pregnant and lactating hamsters. Journal of Endocrinology 63 125-135.

Bhatt H, Brunet LJ \& Stewart CL 1991 Uterine expression of leukemia inhibitory factor coincides with the onset of blastocyst implantation. PNAS 88 11408-11412.

Bilinski P, Roopenian D \& Gossler A 1998 Maternal IL-1R function is required for normal deciduas and fetoplacental development in mice. Genes and Development 12 2235-2243. 
Callard R \& Gearing A 1994 The Cytokine Facts Book, pp 163-167. London: Academic Press.

Carson DD, Bagchi I, Dey SK, Enders AC, Fazleabas AT, Lessey BA \& Yoshinaga K 2000 Embryo implantation. Developmental Biology 223 217-237.

Chen H-F, Shew J-Y, Ho H-N, Hsu W-L \& Yang Y-S 1999 Expression of leukemia inhibitory factor and its receptor in preimplantation embryos. Fertility and Sterility 72 713-719.

Cheng J-G, Chen JR, Hernandez L, Alvord WG \& Stewart CL 2001 Dual control of Lif expression and Lif receptor function regulate Stat3 activation at the onset of uterine receptivity and embryo implantation. PNAS 98 8680-8685.

Cheng J-G, Rodriguez CI \& Stewart CL 2002 Control of uterine receptivity and embryo implantation by steroid hormone regulation of Lif production and Lif receptor activity: towards a molecular understanding of 'the window of implantation'. Reviews in Endocrine and Metabolic Disorders 3 119-126.

Classen-linke I, Muller-Newe G, Heinrich PC, Bier HM \& von Rango U 2004 The cytokine receptor gp130 and its soluble form are under hormonal control in human endometrium and decidua. Molecular Human Reproduction 10 495-504.

Conquest F \& Brulet P 1990 Developmental expression of myeloid leukemia inhibitory factor gene in preimplantation blastocysts and in extraembryonic tissue of mouse embryos. Molecular and Cellular Biology 10 3801-3805.

Cullinan EB, Abbondanzo SJ, Anderson PS, Pollard JW, Lessey BA \& Stewart CL 1996 Leukemia inhibitory factor and Lif receptor expression in human endometrium suggests a potential autocrine/paracrine function in regulating embryo implantation. PNAS 93 3115-3120.

Deanesly R 1960 Normal implantation in ovariectomized guinea pigs. Nature 186 327-328.

Dickmann Z, Dey SK \& Sengupta J 1976 A new concept: control of early pregnancy by steroid hormones originating in the preimplantation embryo. Vitamins and Hormones 34 215-242.

Dimistriadis E, Salamonsen LA \& Robb L 2000 Expression of interleukin -11 during human menstrual cycle: coincidence with stromal cell decidualization and relationship to leukemia inhibitory factor and prolactin. Molecular Human Reproduction 6 907-914.

Dunglison QF, Barlow DH \& Sargent IL 1996 Leukemia inhibitory factor significantly enhances the blastocyst formation rate of human embryos cultured in serum free medium. Human Reproduction 11 191-196.

Gearing DP 1993 The leukemia inhibitory factor and its receptor. Advances in Immunology 53 31-58.

Gearing DP, Comeau MR, Friend DJ, Gimpel SD, Thut CJ, McGourty J, Brasher KK, King JA, Gillis S, Mosley B et al. 1992 The IL-6 signal tranducer, gp130: an oncostatin $\mathrm{M}$ receptor and affinity converter for the Lif receptor. Science 255 1434-1437.

George FW \& Wilson JD 1978 Estrogen formation in the early rabbit embryo. Science 199 200-201.

Ghosh D, De P \& Sengupta J 1994 Luteal phase ovarian estrogen is not essential for implantation and maintenance of pregnancy from surrogate embryo transfer in the rhesus monkey. Human Reproduction 9 629-637.

Harper MJK, Dowd D \& Elliot ASW 1969 Implantation and embryonic development in the ovariectomized-adrenalactomized hamster. Biology of Reproduction 1 253-257.

Heap RB, Flint APF \& Gadsby JE 1981 Embryonic signals and maternal recognition. In Cellular and Molecular Aspects of Implantation, pp 311-325. Eds S Glasser \& DW Bullock. New York: Plenum Press.

Hilton DJ 1992 Lif: lots of interesting functions. Trends in Biochemical Sciences 17 72-76

Hilton DJ, Hilton AA, Raicevic A, Rakar S, Harrison-Smith $M$, Gough NM, Begley CG, Metcalf D, Nicola NA \& Willson TA 1994 Cloning of a murine IL-11 receptor alpha chain; required for gp130 for high affinity binding and signal transduction. EMBO Journal 13 4765-4775.

Hoversland RC, Dey SK \& Johnson DC 1982 Aromatase activity in the rabbit blastocyst. Journal of Reproduction and Fertility 66 259-263.

Jurisicova A, Ben-chetrit A, Varmuza SL \& Casper RF 1995 Recombinant human leukemia inhibitory factor does not enhance in vitro human blastocyst formation. Fertility and Sterility 64 999-1002.
Kojima K, Kanzaki H, Iwai M, Hatayama H, Fujimoto M, Inoue T, Hori K, Nakayama H, Fujita J \& Mori T 1994 Expression of leukemia inhibitory factor in human endometrium and placenta. Biology of Reproduction $\mathbf{5 0}$ 882-887.

Leavitt WW \& Blaha GC 1970 Circulating progesterone levels in the golden hamster during the estrous cycle, pregnancy and lactation. Biology of Reproduction 3 353-361.

Li R, Hartley L \& Robb L 2001 Cloning of rat interleukin-11 and interleukin 11 receptor alpha chain and analysis of their expression in rat uterus in the peri-implantation period. Reproduction 122 593-600.

Lindberg MK, Moverare S, Eriksson AL, Skrtic S, Gao H, Dahlman-Wright K \& Gustafsson JA 2002 Identification of estrogen-regulated genes of potential importance for the regulation of trabecular bone mineral density. Journal of Bone and Mineral Research 17 2183-2195.

Meyer RK, Wolf RC \& Arslan M 1969 Implantation and maintenance of pregnancy in progesterone treated ovariectomized monkeys (Macaca mulatta). In: Recent Advances in Primatology, vol 2, pp 30-35. Basal: S Karger.

Modric T, Kowalski AA, Green ML, Simmen RCM \& Simmen FA 2000 Pregnancy-dependent expression of leukemia inhibitory factor (Lif), Lif receptor- $\beta$ and interleukin- 6 (IL-6) messenger ribonucleic acids in the porcine female reproductive tract. Placenta 21 345-353.

Murray R, Lee F \& Chiu C-P 1990 The genes for leukemia inhibitory factor and interleukin- 6 are expressed in mouse blastocysts prior to the onset of hemopoiesis. Molecular and Cellular Biology 1 4990-4956.

Nachtigall MJ, Kliman HJ, Feinberg RF, Olive DL, Engin O \& Arici A 1996 The effect of Lif on trophoblast differentiation: a potential role in human implantation. Journal of Clinical Endocrinology and Metabolism 81 801-806.

Ni H, Ding N-Z, Harper MJK \& Yang Z-M 2002 Expression of leukemia inhibitory factor receptor and gp130 in mouse uterus during early pregnancy. Molecular Reproduction and Development 63 143-150.

Nichols J, Davidson D, Taga T, Yoshida K, Chambers I \& Smith A 1996 Complementary tissue specific expression of Lif and Lif-receptor mRNAs in early mouse embryogenesis. Mechanisms of Development $\mathbf{5 7}$ 123-131.

Orsini MW \& Meyer RK 1962 Effects of varying doses of progesterone on implantation in the ovariectomized hamster. Proceedings of the Society for Experimental Biology and Medicine 110 713-715.

Paria BC, Huet-Hudson YM \& Dey SK 1993 Blastocyst's state of activity determines the 'window' of implantation in the receptive mouse uterus. PNAS 90 10159-10162.

Paria BC, Reese J, Das SK \& Dey SK 2002 Deciphering the cross-talk of implantation: advances and challenges. Science 262 2185-2188.

Perry JS, Heap RB \& Amoroso EC 1973 Steroid hormone production by pig blastocysts. Nature 245 45-47.

Prasad MRN, Orsini MW \& Meyer RK 1960 Nidation in progesterone-treated, estrogen-deficient hamsters, Mesocricetus auratus (Waterhouse). Proceedings of the Society for Experimental Biology and Medicine 104 48-51.

Psychoyos A 1973 Endocrine control of egg implantation. In Handbook of Physiology, pp 187-215. Eds RO Greep, EG Astwood \& SR Geiger. Washington DC: American Physiological Society.

Rathjen PD, Toth S, Willis A, Heath JK \& Smith AG 1990 Differentiation inhibiting activity is produced in matrix-associated and diffusible forms that are generated by alternate promoter usage. Cell 62 1105-1114.

Robb L, Li R, Hartley L, Nandurkar HH, Koentgenn F \& Begley CG 1998 Infertility in female mice lacking the receptor for interleukin 11 is due to a defective uterine response to implantation. Nature Medicine 4 303-308.

Sawai K, Matsuzaki N, Kameda T, Hashimoto K, Okada T, Shimoya K, Nobunaga T, Taga T, Kishimoto T \& Saji F 1995 Leukemia inhibitory factor produced at the fetomaternal interface stimulates chorionic gonadotrophin production: its possible implication during pregnancy, including implantation period. Journal of Clinical Endocrinology and Metabolism 80 1449-1456.

Sawai K, Matsuzaki N, Okada T, Shimoya K, Koyama M, Azuma C, Saji F \& Murata Y 1997 Human decidual cell biosynthesis of leukemia inhibitory factor: regulation by decidual cytokines and steroid hormones. Biology of Reproduction 56 1274-1280.

Sharkey AM, Dellow K, Blayney M, Macnamee M, Charnock-Jones S \& Smith SK 1995 Stage-specific expression of cytokines and receptor messenger ribonucleic acids in human preimplantation embryos. Biology of Reproduction 53 974-981. 
Sholl SA, Orsini MW \& Hitchins DJ 1983 Estrogen synthesis and metabolism in the hamster blastocyst, uterus and liver near the time of implantation. Journal of Steroid Biochemistry 19 1153-1161.

Song H \& Lim H 2006 Evidence for heterodimeric association of leukemia inhibitory actor (Lif) receptor and gp130 in the mouse uterus for Lif signaling during blastocyst implantation. Reproduction 131 341-349.

Song H, Lim H, Das SK, Paria BC \& Dey SK 2000 Dysregulation of EGF family of growth factors and COX-2 in the uterus during the preattachment and attachment reactions of the blastocyst with the luminal epithelium correlates with implantation failure in Lif-deficient mice. Molecular Endocrinology 14 1147-1161.

Stewart CL, Kaspar P, Brunet LJ, Bhatt H, Gadi I, Kontgen F \& Abbondanzo SJ 1992 Blastocyst implantation depends on maternal expression of leukemia inhibitory factor. Nature 359 76-79.

Tsai HD, Chang CC, Hsieh YY \& Lo HY 2000 Leukemia inhibitory factor expression in different endometrial locations between fertile and infertile women throughout different menstrual phases. Journal of Assisted Reproduction and Genetics 17 415-418.

Wang X, Wang H, Matsumoto H, Roy SK, Das SK \& Paria BC 2002 Dual source and target of heparin-binding EGF-like growth factor during the onset of implantation in the hamster. Development 129 4125-4134.

Wang X, Su Y, Deb K, Raposo M, Morrow JD, Reese J \& Paria BC 2004 Prostaglandin E2 is a product of induced prostaglandin-endoperoxide synthase 2 and microsomal-type prostaglandin $E$ synthase at the implantation site of the hamster. Journal of Biological Chemistry 279 30579-30587.

Ware CB, Horowitz MC, Renshaw BR, Hunt JS, Liggitt D, Koblar SA, Gliniak BC, McKenna HJ, Papayannopoulou T, Thoma B et al. 1995
Targeted disruption of the low-affinity leukemia inhibitory factor receptor gene causes placental, skeletal, neural and metabolic defects and results in perinatal death. Development 121 1283-1299.

Yoshida K, Taga T, Saito M, Suematsu S, Kumanogoh A, Tanaka T, Fujiwara H, Hirata M, Yamagmi T, Nakahata T et al. 1996 Targeted disruption of gp130, a common signal tranducer for the interleukin 6 family of cytokines, leads to myocardial and hematological disorders. PNAS 93 407-411.

Yoshinaga K \& Adams CE 1966 Delayed implantation in the spayed progesterone treated adult mouse. Journal of Reproduction and Fertility 12 593-595.

Yue ZP, Yang ZM, Wei P, Li SJ, Wang HB, Tan JH \& Harper MJK 2000 Leukemia inhibitory factor, leukemia inhibitory factor receptor and glycoprotein 130 in rhesus monkey uterus during menstrual cycle and early pregnancy. Biology of Reproduction 63 508-512.

Zegers-Hochschild F \& Altieri E 1995 Luteal estrogen is not required for the establishment of pregnancy in the human. Journal of Assisted Reproduction and Genetics 12 224-228.

Zhang Q \& Paria BC 2006 Importance of uterine cell death, renewal and their hormonal regulation in hamsters that show progesterone-dependent implantation. Endocrinology 147 2215-2227.

Received 8 January 2007

First decision 6 February 2007

Revised manuscript received 28 September 2007

Accepted 16 October 2007 